\title{
The Effects of Two Stage Selection Based \\ on Performance and Progeny Testing \\ on the Genetic Gains
}

\author{
Fumio Mukai, Kayo Kitayama and Toyokazu Fukushima \\ Faculty of Agriculture, Kobe University, Kobe-shi 657
}

(Received August 12, 1983)

\begin{abstract}
The effects of two stage selection on genetic gains of two traits each independently subjected to selection were examined over 10 generations. Unselected popula tion size at each generation was 1,000 , in which sex was specified with the probability of 0.5 . Selection at stage 1 was based on phenotypic value of trait 1 with a selected fraction: $10 \%$ for males and $40 \%$ for females. At stage 2, half of the males were selected based on the progeny mean of trait 2. Total capacity of progeny testing was limited to 300. The traits were controlled additively by 14 loci each with two alleles. Gene frequency in the base population was arbitrarily set at 0.5 at each locus. Assumed initial heritabilities of trait 1 and trait $2\left(h^{2}{ }_{10}\right.$ and $\left.h^{2}{ }_{20}\right)$ were $0.6,0.4$, or 0.2 , and genetic correlation $\left(r_{80}\right)$ was $0.16,0.0$ or -0.16 , which was generated by regulating the number and the kinds of pleiotropic loci affecting the traits. All combinations of three heritabilities and three genetic correlations were simulated. The additive genetic variances and heritabilities decreased rapidly at $\mathrm{h}^{2}{ }_{10}=0.6$ and $\mathrm{h}^{2}{ }_{20}=0.2$, while the decline in covariances and genetic correlations was considerable in the reverse heritability combination. There were no remarkable effects of two stage selection on the cumulative genetic gains of trait 1 ( $\triangle C G 1$ ) over a short term at all genetic parameter combinations, although when $\mathrm{h}^{2}{ }_{10}$ and $\mathrm{r}_{\mathrm{g} \text { o }}$ were lower, $\triangle \mathrm{CGl}$ over a long term were slightly less than those by performance testing selection alone. The cumulative genetic gains of trait 2 ( $\triangle \mathrm{CG} 2$ ) differed according to the parameter combinations. $\triangle C G 2$ were considerably less than those attained by progeny testing selection alone, except in the case of $\mathrm{h}_{20}{ }_{20}=0.2$ and $\mathrm{r}_{\mathrm{go}}=$ 0.16 , in which larger $\triangle \mathrm{CG} 2$ relative to the control were observed owing to favorable correlated responses from first stage selection. The decline of $\triangle \mathrm{CG} 2$ became more clear with higher $h^{2}{ }_{10}$ and lower $r_{g 0}$ : for example, negative $\triangle$ CG2 were found when $h_{10}^{2}=0.6$ or 0.4 and $r_{\mathrm{g} 0}=-0.16$.

Jpn. J. Zootech. Sci., 55 (5): $322-331,1984$
\end{abstract}

In animal breeding, animals may be subjected to selection at several stages of their life as information from ancestors, own performance, contemporaries and offspring are subsequently obtained. The improvement of aggregate genotype and/or genotype of component traits is greatly affected by genetic correlations and selection intensities at each stage, as well as by heritabilities and additive genetic variances. In addition, the genetic parameters in population change during the course of the selection as a result of selection itself and of random drift caused by small effective population size. In these situations, it is very difficult, if not impossible, to estimate genetic progress over a long term by a deterministic model.

These difficulties may be overcome to a large degree by using high speed computer simulation. Early work in Monte Carlo simulation in genetics was done by 
FrASER $^{1.2)}$ and BARKER ${ }^{3,4)}$. The advantage of Monte Carlo simulation using random numbers is that it makes it possible to imitate the entire genetic system of selection of parents, Mendelian segregation and recombination, and the subsequent determination of individual genotypes and phenotypes in succeeding generations.

The objective of this study is to investigate the effects of two stage selection on the genetic parameters and the genetic gains for two traits which are selected independently at different stages, using the Monte Carlo simulation method.

\section{Materials and Methods}

\section{Determination of Genotypic and Phenotypic Values}

Two traits considered in this study were assumed to be controlled by the additive mode of gene action. Trait 1 is measured by performance testing, while trait 2 can be measured only by progeny testing.

Each trait is controlled by fourteen loci with two possible kinds of alleles. The fourteen loci were divided into two groups composed of seven loci each. The genotype of each individual constituting the base population was assigned a binary digit " 0 " or "1" by a random process. If the uniform random number was less than or equal to 0.5 , the " 0 " allele was assigned, while if the random number was greater than 0.5 , the other allele, "1", was assigned. This procedure was repeated for each of the two alleles at 14 loci and allowed the population to come to linkage equilibrium. The initial gene frequency is expected to be 0.5 at each locus, so that the additive genetic variance would be at a maximum. In subsequent generations, Mendelian segregation and recombination, and gametogenesis were simulated using the random walk method. Each offspring received one gamete from its sire and the other from its dam. The recombination rate between adjacent pairs of loci was set at 0.5 , because GILL ${ }^{5}$ and YounG $^{6)}$ confirmed that linkage influenced neither the selection advance nor the proportion of genetic variance to total variance in large population.

To determine the genotypic value, we assigned one of three kinds of additive gene effect $(+1,0$ and -1$)$ to allele " 1 " and assigned 0 to allele " 0 ". Thus five types of the genotypic values $(+2,+1,0,-1$ and -2$)$ might be generated at overall loci. Individual total genotypic value for the trait was calculated by summing over the value of 14 loci. Individual phenotypic value was determined by adding the environmental deviation to the total genotypic value. The environmental deviations were generated from normal distribution with zero mean and environmental variance, the size of which was determined according to initial additive genetic variance and heritability and was assumed not to change during the successive generations. Correlations between genotype and environment and among environments were also set at zero at the start.

\section{Specification of Genetic Parameters}

The initial heritabilities of the traits, which was denoted by $h^{2}{ }_{10}$ for trait 1 and by $\mathrm{h}^{3}{ }_{90}$ for trait 2 , were set at $0.6,0.4$ or 0.2 .

We assumed that the genetic correlation results from pleiotropic effect of allele " 1 " 
at each locus. The initial size of genetic correlation denoted by $r_{g o}$, was $0.16,0.0$ or -0.16 , which was generated by regulating the number and the kinds of the additive gene effect on each trait considering the schemes suggested by BOHREN et al. ${ }^{7}$ and SHERIDAN and BARKER ${ }^{8}$. When genetic correlation of 0.16 was assumed, alleles " 1 " at two out of 14 loci had +1 additive effect on trait 1 , but no effect on trait 2 . Two other loci affected the traits in the opposite manner. Alleles at six other loci had +1 effect on both traits. Alleles at the remaining four loci affected the traits in a reverse manner, +1 or -1 . These three different pleiotropic actions are referred to as independent, the same and reverse actions in the following section. On simulating the genetic correlation of zero, the number of loci having independent, the same and reverse actions were 6,4 and 4 , respectively. On the genetic correlation of -0.16 , 4 independent, 4 same and 6 reverse additive action loci were designated. The expected additive genotypic mean, the additive variance and covariance in the base population were 8,6 and 1 at $r_{g o}=0.16,7,5.5$ and 0 at $r_{g o}=0.0$, and 6,6 and -1 at $r_{g 0}=-0.16$. The expected maximum genotypic values were 20,18 and 18 , respectively.

\section{Breeding Method}

Each population with the particular genetic parameter combination was subjected to simulation of selection following breeding process until 10th generation. Population size in each generation was 1,000 , where the sex of each animal was specified by random number from binomial distribution with a probability of 0.5 .

In first stage selection, males and females were ranked in descending order based on phenotypic value of trait 1 and were selected truncationally at the selected fraction$10 \%$ for males and $40 \%$ for females. Selected males were mated with females at random to produce offspring for progeny testing. Total capacity of progeny testing was limited to 300 . Half of the males (final selected fraction equal to $5 \%$ ) were selected based on their progeny phenotypic mean of trait 2 . These finally selected males were randomly mated with females selected at the first stage by sampling with replacements, and each mating produced one offspring. These processes were repeated, avoiding the production of full sib until one thousand offspring were generated. Generation was assumed to be non-overlapping.

Genotypic and phenotypic means, additive genetic variance and heritability, and genetic covariance and genetic correlation were measured in each offspring generation. The variance and covariance were calculated by multiplying gene frequencies by additive gene effects. The cumulative genetic gains in standard deviation units were expressed as a percentage of the control value which was attained in the 10th generation only by one stage selection. The control values for trait 1 were obtained by performance testing and for trait 2 by progeny testing alone. To equalize the final selection percentage, corresponding fractions of males and females were randomly chosen at each stage when selection was not practiced in the control. Duplicated runs were made for each parameter combination. 


\section{Results and Discussion}

Differences between the results from duplicated runs at every genetic parameter combination were negligible so that the assumed population size seemed to be large enough to disregard random drift. Therefore, all statistics presented were averaged over two replicates.

It is necessary to understand the behavior of genetic parameters in the population under selection for formulating the breeding plans and predicting the long term response of selection. Figure 1-A shows the change in additive genetic variances and covariances only under the combination of two extreme heritabilities $(0.6$ vs. 0.2$)$ at the three levels of $r_{\text {go. }}$.
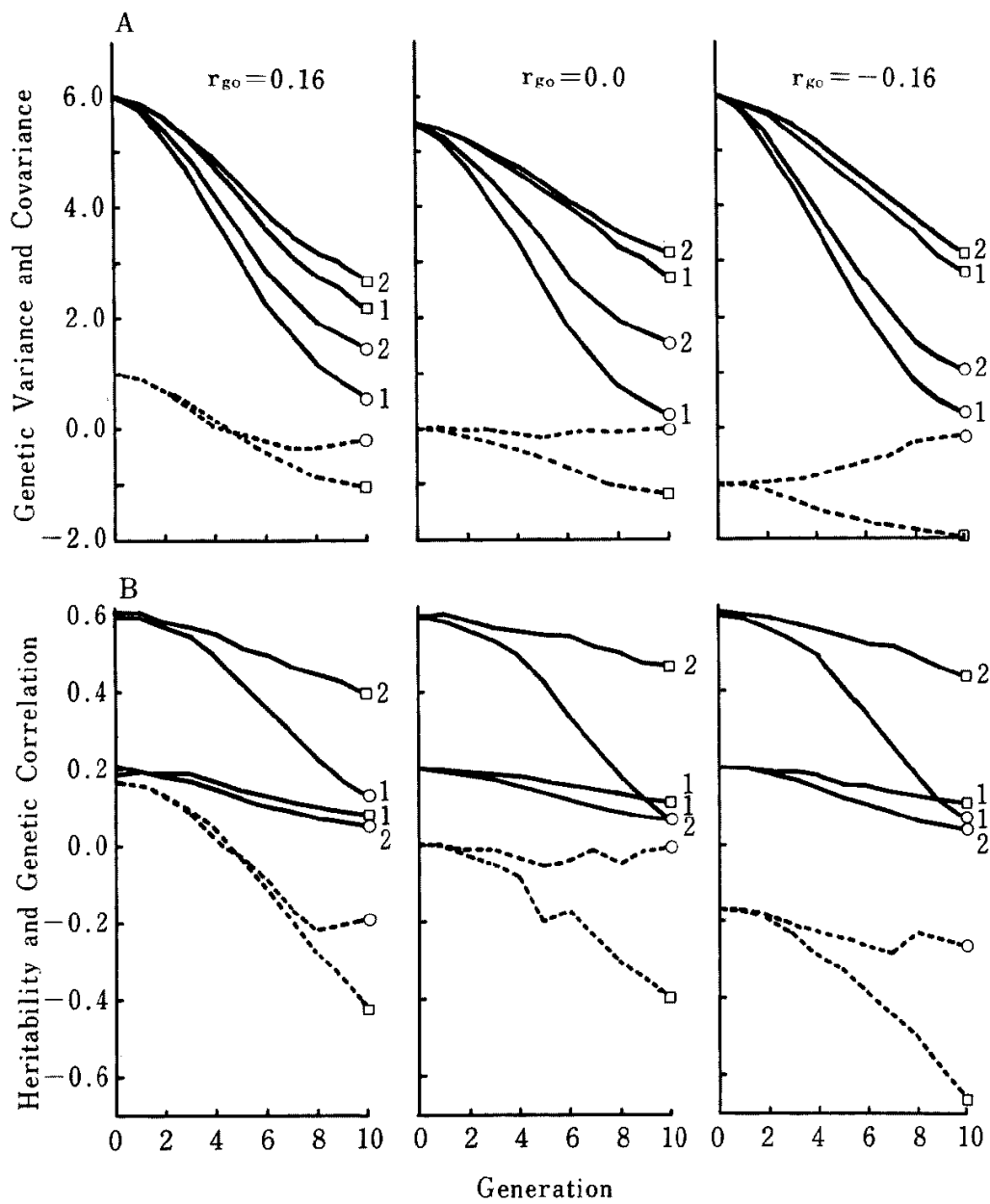

Fig. 1. Change in additive genetic variance and covariance (A), and heritability and genetic correlation (B) with the generation of selection. $r_{80}$ indicates the initial genetic correlation. A solid line indicates the additive genetic variance or heritability and a broken line the additive covariance or genetic correlation at the initial heritability of trait $1, h^{2}{ }_{10}=0.6$ and trait $2, h^{2}{ }_{20}=0.2(0)$, and $h^{2}{ }_{10}=0.2$ and $h^{2}{ }_{20}=0.6(\square)$. Figures 1 and 2 denote trait 1 subjected to performance and trait 2 subjected to progeny testing, respectively. 
Additive genetic variances for both traits decreased below half of initial levels. The rate of decay was more rapid at $h^{2}{ }_{10}=0.6$ and $h^{2}{ }_{20}=0.2$ than at $h_{10}^{2}=0.2$ and $\mathrm{h}^{2}{ }_{20}=0.6$, and the difference between the heritability combinations became so clear at negative $\mathrm{r}_{\text {go. }}$. It is apparent that the rate of decay is affected appreciably by the combination of heritability. On the other hand, the covariances decreased steadily when $h^{2}{ }_{10}$ and $h^{2}{ }_{20}$ were 0.2 and 0.6 , respectively. When $h^{2}{ }_{10}=0.6$ and $h^{2}{ }_{20}=0.2$, however, the change in covariances was different according as $\mathrm{r}_{\mathrm{go}}$ was positive or negative.

In general, these phenomena relate directly to the relative changes in gene frequencies at various loci. The fixation rate for alleles was faster at loci with the same pleiotropic effect than at loci with the reverse effect (data not shown). As to the latter loci, the allele " 1 " with the effect +1 on trait 1 but -1 on trait 2 at some loci and the allele " 0 " at the other loci where the allele " 1 " has the effect -1 on trait 1 but +1 on trait 2 will be brought to fixation primarily. The reason for decreasing the variances to lesser extent at the combination of $h^{2}{ }_{10}=0.2$ and $h^{2}{ }_{20}=0.6$ is that the fixation rate at the reverse pleiotropic loci became slower as compared with the reverse heritability combination, because the accuracy of first stage selection was low. Then the greater part of those loci still segregated in the 10th generation. The behavior of the covariances also reflects the change in the gene frequency at each locus. Selection causes the change of the covariance in positive or negative direction based on the assumed covariance structure. The delay of fixation at loci with the reverse effect in the combination of $h^{2}{ }_{10}=0.2$ and $h^{2}{ }_{20}=0.6$ changed the covariance from the initial to a negative lower value. When $\mathrm{h}^{2}{ }_{10}$ was 0.6 , however, the covariances at all $\mathrm{r}_{\text {go }}$ converged on zero because most loci moved on toward the fixation.

The change in heritabilities and genetic correlations is given in Figure 1-B. In the case of the heritability combination of $h^{2}{ }_{10}=0.6$ and $h^{2}{ }_{20}=0.2$, reflecting the decay of the variance, heritabilities of trait 1 declined rapidly from 0.6 to 0.13 at $\mathrm{r}_{\mathrm{go}}=0.16$, to 0.07 at $\mathrm{r}_{\mathrm{go}}=0.0$, and to 0.06 at $\mathrm{rgo}_{\mathrm{go}}=-0.16$ in the 10th generation. Those of trait 2 also decreased to about 0.05 at all $r_{\text {go }}$. As to genetic correlation in this heritability combination, when $\mathrm{r}_{\mathrm{go}}$ was 0.16 , it decreased to -0.20 . However, the correlations remained near those assumed at the beginning when $r_{\mathrm{go}}=0.0$ and $\mathrm{r}_{\mathrm{go}}=-0.16$. In the reverse heritability combination, the extent of decay of heritabilities was a little for both traits. On the contrary, the correlations decreased rapidly from each initial values to negative ones. These items of evidence show that a great reduction in genetic correlation occurs when $h_{20}^{2}$ is higher in contrast to $h^{2}{ }_{10}$.

LERNER $^{9)}$ and $\mathrm{F}_{A L C O N E R^{10}}{ }^{10}$ suggested the genetic correlation would eventually become negative if both traits were selected simultaneously in the same direction. PARKER et al. ${ }^{11)}$ simulated the genetic correlation between two pleiotropic traits, only one of which was selected. They indicated that selection reduced the correlation and the amount of reduction depended on heritability of the selected trait rather than on degree of truncation selection. McMillan et al. ${ }^{12)}$ demonstrated that when selection was applied to selection index, the change of genetic correlation with selection was 
Two-Stage Selection and Genetic Gains

Table 1. Cumulative genetic gains in standard deviation units in 10 th generation by simulating only the first stage selection for trait 1 (performance testing) or only the second stage selection for trait 2 (progeny testing).

\begin{tabular}{|c|c|c|c|c|c|c|}
\hline \multirow{2}{*}{$\begin{array}{l}\text { Initial Genet. } \\
\text { Correlation }\end{array}$} & \multicolumn{3}{|c|}{ Trait 1} & \multicolumn{3}{|c|}{ Trait 2} \\
\hline & 0.6 & $\begin{array}{l}\mathrm{h}^{2}{ }^{20} \\
0.4\end{array}$ & 0.2 & 0.6 & $\begin{array}{l}\mathrm{h}^{2}{ }_{20} \\
0.4\end{array}$ & 0.2 \\
\hline$r_{\mathrm{g} 0}=0.16$ & 4.36 & 3.21 & 1.94 & 1.87 & 1.34 & 0.48 \\
\hline$r_{g 0}=0.0$ & 4.20 & 3.05 & 1.90 & 1.91 & 1.03 & 0.52 \\
\hline$r_{\mathrm{g} 0}=-0.16$ & 4.42 & 3. 20 & 1.93 & 1.67 & 1.22 & 0.64 \\
\hline
\end{tabular}

largely affected by the initial value and the relative weight on each trait in the index. Our results indicate that the pattern of change in the genetic correlation depends on not only its initial level but also the combination of heritabilities of the traits subjected to selection at each stage.

Table 1. shows the cumulative genetic gains in standard deviation units of the traits which were achieved by performance testing alone and by progeny testing alone in the 10th generation. As expected, there was no difference in gains irrespective of $\mathrm{r}_{\mathrm{go}}$. The genetic progress was larger as the trait had higher initial heritability.

The cumulative genetic gains of trait $1(\triangle \mathrm{CG} 1)$ by means of two stage selection are given in Figure 2 except for $\triangle \mathrm{CG} 1$ achieved at $\mathrm{h}^{2}{ }_{10}=0.4$, which progressed between those at the two extremes $h_{10}^{2}(0.6$ and 0.2$)$. There were some differences in $\triangle$ CG1 according to the assigned initial heritability combination. That is, when $\mathrm{h}^{2}{ }_{10}$ was $0.6, \triangle \mathrm{CG} 1$ in the 10 th generation were attained at about $95 \%$ of the corresponding control. When $\mathrm{h}^{2}{ }_{10}=0.2, \triangle \mathrm{CG} 1$ at the same period decreased slightly to $70-90 \%$ of the control. No remarkable effect on the level of $r_{g o}$ on $\triangle \mathrm{CG} 1$ was found when $\mathrm{h}^{2}{ }_{10}$ was high. However, when $\mathrm{h}^{2}{ }_{10}=0.2$, the decline in $\triangle \mathrm{CG} 1$ became greater

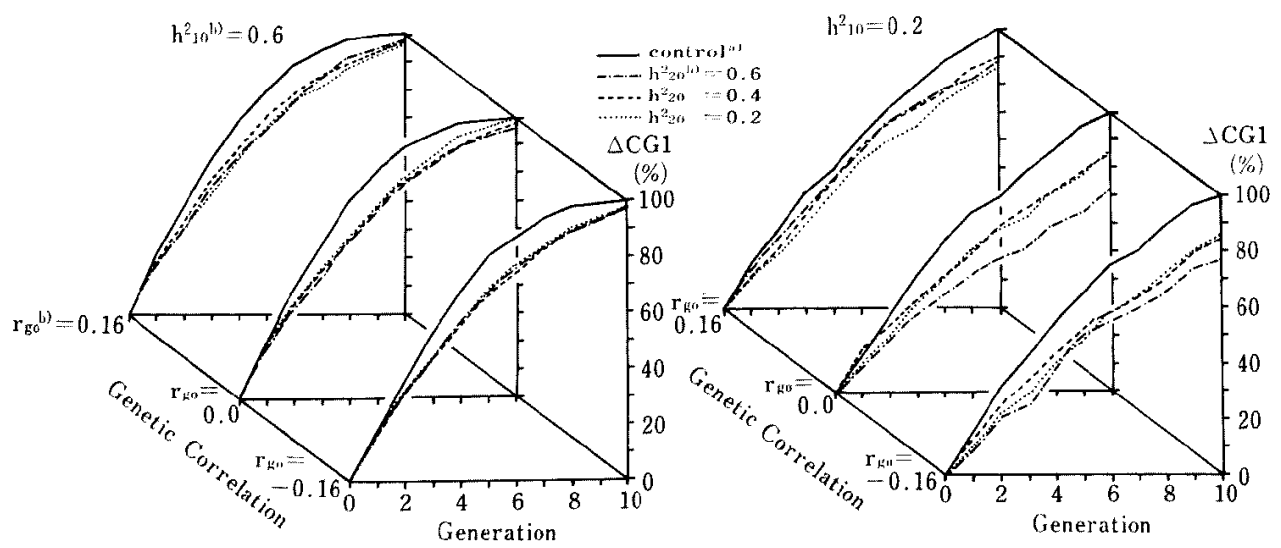

Fig. 2. Cumulative genetic gains of trait $1(\triangle \mathrm{GCl})$ in percentage relative to control value. a) The control was attained in 10 th generation by means of only the first stage selection for trait 1 (performance testing). ${ }^{b /} h^{2}{ }^{2}$ and $r_{g}$ o denote the initial heritability of trait $i(i=1,2)$ and the initial genetic correlation, respectively. 

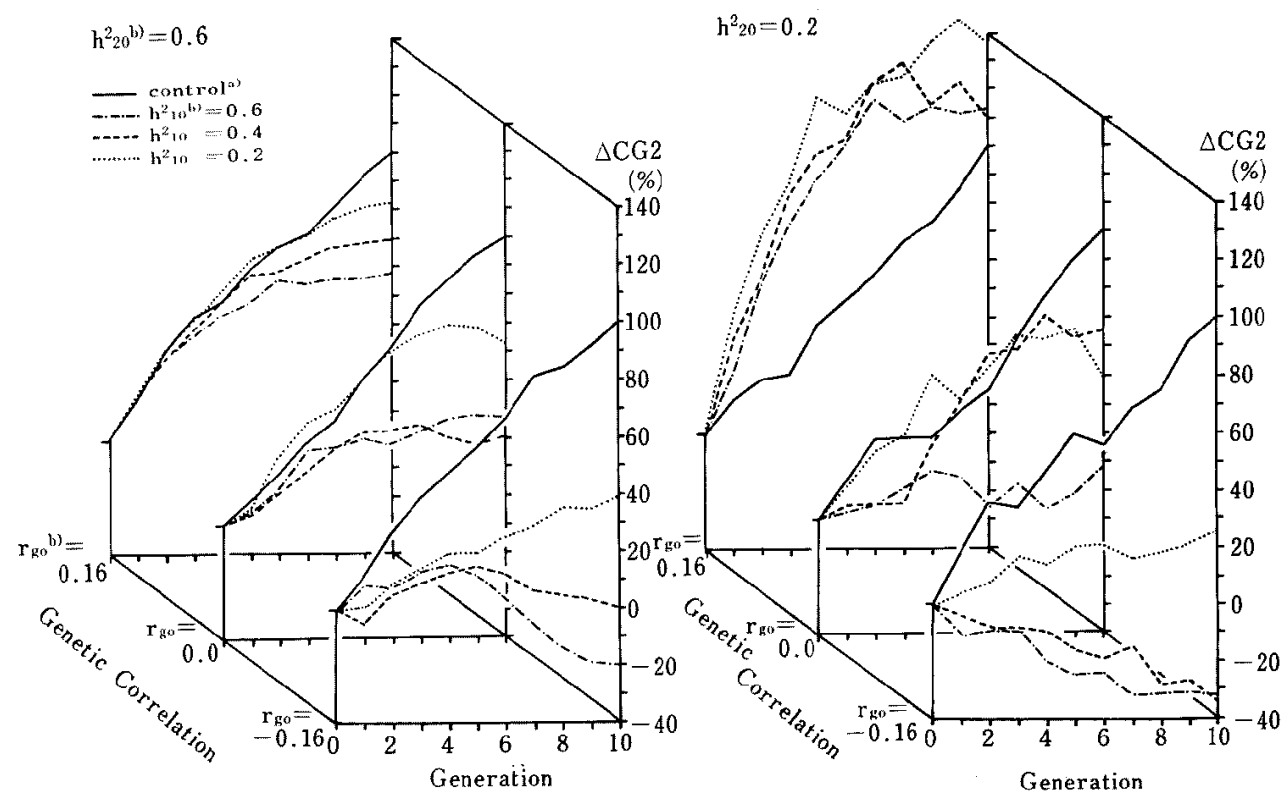

Fig. 3. Cumulative genetic gains of trait $2(\triangle \mathrm{CG} 2)$ in percentage relative to control value. ${ }^{3)}$ The control was attained in 10 th generation by means of only the second stage selection for trait 2 (progeny testing). ${ }^{b} \mathrm{~h}^{2}{ }_{\mathrm{i}}$ and $\mathrm{r}_{\mathrm{g}}$ denote the initial heritability of trait $\mathrm{i}(\mathrm{i}=1,2)$ and the initial genetic correlation, respectively.

with lower $r_{g o}$, and was also affected by the size of $h^{2}{ }_{20}$. The lowest $\triangle$ CG1 was attained at $\mathrm{h}^{2}{ }_{20}=0.6$.

Figure 3 shows the change in cumulative genetic gains of trait $2(\triangle \mathrm{CG} 2)$ during 10 generations.

$\triangle \mathrm{CG} 2$ at $\mathrm{r}_{\mathrm{go}}=0.16$ were as follows: when $\mathrm{h}^{2}{ }_{20}$ was $0.6, \triangle \mathrm{CG} 2$ were nearly equal to those of the control during the first few generations. Thereafter, they decreased over a long term and the amount of reduction had a tendency to be great at $\mathrm{h}^{2}{ }_{10}=0.6$. When $\mathrm{h}^{2}{ }_{20}=0.2$, much greater progress as compared with those of the control was observed in every generation. The greater part of the increase was caused by the favorable correlated response expected from first stage selection during earlier generations. The causes leading to those great increases are that both the accuracy and the intensity of selection at the first stage are relatively greater than those at the second stage.

$\triangle \mathrm{CG} 2$ at $\mathrm{r}_{\mathrm{go}}=0.0$ were as follows: $\triangle \mathrm{CG} 2$ were generally less than those attained under positive $r_{\text {go. }} \triangle \mathrm{CG} 2$ were about $30-40 \%$ of the control when $\mathrm{h}^{2}{ }_{20}=0.6$ and $\mathrm{h}^{2}{ }_{10}=$ 0.4 or 0.6 , and about $70 \%$ when $h^{2}{ }_{20}=0.6$ and $h^{2}{ }_{10}=0.2$. The reason for relatively lower $\triangle \mathrm{CG} 2$ in the former case is as follows. Both ends of distribution of trait 2 are cut off by the first stage selection so that favorable alleles for trait 2 become low. Moreover, this tendency is enhanced as heritability of trait 1 is higher, because the frequencies of favorable alleles for trait 1 but unfavorable for trait 2 increase at reverse pleiotropic loci in the selected population. Furthermore, the great portion of 
final $\triangle \mathrm{CG} 2$ were already achieved till 5 th generation. In the case of the combination being $h^{2}{ }_{20}=0.2$ and $h_{10}^{2}=0.6, \triangle C G 2$ were negligible.

$\triangle \mathrm{CG} 2$ at $\mathrm{r}_{\mathrm{go}}=-0.16$ were as follows: $\triangle \mathrm{CG} 2$ remarkably decreased as compared with those of the control and of other $r_{\text {go }}$ level, and there was a striking difference among the heritability combinations. Even in the condition of $h^{2}{ }_{10}=0.2$, finaly attained $\triangle \mathrm{CG} 2$ were limited to only $20-40 \%$. Furthermore, when $\mathrm{h}^{2}{ }_{10}=0.6$, negative $\triangle \mathrm{CG} 2$ in later generations were found at every $\mathrm{h}^{2}{ }_{\mathbf{2 0}}$. The degree of decline relative to the control was greater and the generation in which $\triangle \mathrm{CG} 2$ turned into the negative became earlier as $h^{2}{ }_{10}$ was higher and $h^{2}{ }_{20}$ was lower. This was naturally expected because of negative genetic correlation with trait 1 resulting in unfavorable correlated response in trait 2 . This tendency seemed to be enhanced by decreasing genetic correlation as generations proceeded.

These results indicate that the effect of first stage selection on $\triangle \mathrm{CG} 2$ could be significant, since the genetic structure in the selected population changed with selection. Then the initial selection should be considered as part of the total selection plan.

As shown in Figure 2, there was no serious decrease in $\triangle \mathrm{CGI}$ according to the combination of heritability and genetic correlation, there being the opportunity to choose the favorable alleles for trait 1 at first in each generation under selection. On the other hand, $\triangle \mathrm{CG} 2$ differed considerably according to the genetic parameter combination. The gains observed in latter generation were somewhat less than would be predicted from the genetic parameters in the base population. Genetic correlation caused by pleiotropic effect will change from positive to negative under the same directional selection for two traits. Therefore, indirect selection pressure on trait 2 may vary gradually from upward to downward in direction. Thus favorable correlated response is not expected over a long time even in the case of genetic correlation being positive at the beginning of selection. However, the amount of unfavorable correlated response caused by negative genetic correlation would not be so large in later generations because the additive genetic variance also has decreased. The decreasing tendency of $\triangle \mathrm{CG} 2$ caused by high heritability of trait 1 is easily explained by the change in gene frequency. As a result of selecting superior genotype for trait 1 with high frequency at the first stage, favorable alleles for trait 1 will account for a high percentage even at reverse pleiotropic loci. As a phenomenon contrary to this, the frequencies of favorable alleles for trait 2 inevitably become low and so the genetic potentiality for trait 2 would be exhaused in early generation.

In this report, we present the results of only one combination of selection intensities where intensity at the second stage is weak as compared with intensity at the first stage. When stronger intensity is applied at the second stage, $\triangle \mathrm{CG1}$ will slightly decrease, and $\triangle \mathrm{CG} 2$ will change on a large scale because the great effects of correlated response due to the difference in selection intensities between two stages diminish. Of course, the amount of change would largely depend on the change in genetic correlation in the course of selection. Therefore, relatively larger $\triangle \mathrm{CG} 2$ in 
the combination of $\mathrm{h}^{2}{ }^{20}=0.2$ and $\mathrm{r}_{\mathrm{gO}}=0.16$ cannot be expected. QURESHI and KemPTHORNE ${ }^{13)}$ and QURESHI and HAZEL ${ }^{14)}$ reported that when population size was limited and tight linkage between loci existed, the probability of unfavorable alleles being fixed arose and resulted in less genetic advance. Singh and Bellmann ${ }^{16,16)}$ also considered the genetic correlation caused by linkage and showed that the genetic gain per generation under index selection decreased more strongly when heritability was low and genes were closely linked. Following their results, if we simulate under close linkage and higher selection intensity at the first stage in a rather small population, the detrimental effect of first stage selection on trait 2, particularly in the case when $r_{\text {go }}$ is negative or zero, will be clear because there is more possibility of the fixation of unfavorable alleles by random drift before favorable alleles can be fixed by selection. Moreover, close linkage between pleiotropic loci may make the genetic gain more or less unpredictable.

We made several assumptions with respect to the number of loci, gene action and pleiotropic effect, etc. in the present model, some of which may be insufficient for biological reality. In fact the results depend to some extent on how we set up these essential genetic properties. On the other hand, these properties of quantitative traits for farm animals are usually not exactly known. It is actually impossible to evaluate fully the efficiency of the complicated breeding programmes in a real livestock population. Therefore, we must find a solution to the urgent problems step by step within reasonable assumptions. The main practical use of the simulation is to evaluate the effectiveness of various breeding plans taking into account the change in population structure and the deviation from normal distribution in the traits. These trials make it possible to decide easily which plan is applicable with little risk to the actual population in a short time.

In animal breeding, selection is applied for the improvement of the economic value of animals. Economic value usually depends on more than one trait, and the component traits are often evaluated at different stages and by different methods. In such cases multi-stage selection, at least two successive stage selections, must be applied. There are, for example, practical situations where the breeder wishes to improve a trait such as milk yield or carcass quality as well as growth performance. He has to select such a trait by means of progeny testing at great cost of money and time. However, if it has negative lower or no genetic correlation with a highly heritable trait upon which selection at first stage may be practiced, the genetic gain achieved would be smaller than expected and would not be balanced with his investment. Then, it is necessary to consider additional information from relatives at initial selection and alternative breeding plans to compensate the reduction in the genetic gain. One alternative method is to search for the optimum allocation of selection intensity to two stages, as CoTTERILl and JAMES ${ }^{17)}$ and RøNNINGEN ${ }^{18)}$. They investigated the genetic gain within only one generation. Considering the theory of RoBERTSON ${ }^{19}$ ) about maximizing the response at intermediate generations, the situation will be more 
complicated. Further studies will be needed for optimum combination of selection intensities under two stage selection which can ensure the optimum gain.

\title{
References
}

1) Fraser, A. S., Aust. J. Biol. Sci., 10: 484-491. 1957.

2) Fraser, A. S., J. Theoret. Biol., 2: 329-346. 1962.

3) Barker, J.S. F., Aust. J. Biol. Sci., 11: 603-612. 1958.

4) Barker, J. S. F., Aust. J. Biol. Sci., 11: 613-625. 1958.

5) Gill, J. L., Aust. J. Biol. Sci., 18: 599-617. 1965

6) Young, S. S. Y., Genetics, 53: 189-205. 1966.

7) Bohren, B. B., W. G. Hill and A. Robertson, Genet. Res., Camb., 7: 44-57. 1966.

8) Sheridan, A. K. and J. S. F. Barker, Aust. J. Biol. Sci., 27: 89-101. 1974.

9) Lerner, I. M., Population Genetics and Animal Improvement. p90. Cambridge University Press. London. 1950.

10) Falconer, D.S, Introduction to Quantitative Genetics, 2 nd ed. p300. Longman. New York. 1981.

11) Parker, R. J., L. D. McGilliard and J. L. Gill, Theoret. Appl. Genetics, 39: 365-370. 1969.

12) McMillan, I., G. W. Friars and M. Quinton, Anim. Breed. Abstr., 42: 468.1974.

13) Qureshi, A. W. and O. Kempthorne, Theoret. Appl. Genetics, 38: 249-255. 1968.

14) Qureshi, A. W. and L. N. Hazel, Theoret. Appl. Genetics, 38: 256-263. 1968.

15) Singh, R. K. and K. Bellmann, Theoret. Appl. Genetics, 44:63-68. 1974.

16) Singh, R. K. and K. Bellmann, Theoret. Appl. Genetics, 44: 289-293. 1974.

17) Cotterill, P. P. and J. W. James, Theoret. Appl. Genetics, 59: 67-72. 1981.

18) R申nningen, K., Acta Agric. Scand., 20: 71-104. 1970.

19) Robertson, A., Theoret. Poupulation Biol. 1: 120-127. 1970.

\section{能力検定および後代検定による 2 段階選抜の 遺伝的改良量に及ほす影響}

\author{
向井文雄・北山佳世・福島豊一 \\ 神戸大学農学部，神戸市 657
}

能力検定および後代検定の 2 段階にわたる選拔が各段 階の対象形質（形質 1 ; 形留 2) の遗伝的改良量に及ぼす 影製をシミェレーション法により検討した，集団の大き さは 1,000 (倠雄各 500) とし，第 1 段階選拔は形質 1 に よる個体選抜（選抜率は雄 10\%，雌 40\%），第 2 段階は 形質 2 の後代の平均による選抜（選抜率は雄に対しての み50\%)を10世代にわたり実施した。両形質は 2 遺伝 子群上の 2 対立頲伝子を持つ 14 遭伝子座に支配され，基 礎集団の遗伝子頻度はいずれも0.5とした．相加的遗伝 様式を想定して㴯伝子型洒を決定し，表型洒は遗伝子型 価に環境偏差 (NID $\left.\left(0, \sigma_{\mathrm{e}}{ }^{2}\right)\right)$ を加充算出した。初期遺 伝率 $\left(\mathrm{h}^{2}{ }_{10} ; \mathrm{h}^{2}{ }_{20}\right)$ は0.6,0.4 括よび 0.2 を組合わせ, 初 期遗伝相関 $\left(\mathrm{r}_{\mathrm{g}}\right)$ は多面作用による $0.16,0,-0.16$ を 設定した.したがって計 27 通りの選拔春験を実施し，両 形質の累積改良量（ $\triangle \mathrm{CG} 1 ; \triangle \mathrm{CG} 2)$ を算出した．結果
は第 1 あるいは第 2 段階選抜のみを行なった場合の10世 代時の累䅪改良量を対照として\%表示した. $\triangle \mathrm{CG1}$ は中 期までは対照区と大差はないが，後期には $\mathrm{r}_{\mathrm{go}}$ が低く， $\mathrm{h}^{2}{ }_{20}$ が高いほど低下した。 $\triangle \mathrm{CG} 2$ は 2 形質の遗伝率と遗

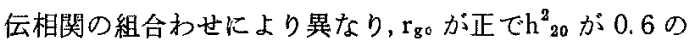
場合， $\triangle \mathrm{CG} 2$ は対照区に比べ低かったが（10世代におい て対照区の 60 80\%), $\mathrm{h}^{2}{ }_{20}$ が 0.2 では間接選抜反応が 加わり大きな $\triangle \mathrm{CG} 2(120 \sim 140 \%)$ を示した。逆に $\mathrm{r}_{\mathrm{g}}$ 。が 真の場合， $\triangle \mathrm{CG} 2$ は著しく低下し，最も高い塲合でむ $40 \%\left(h^{2}{ }_{10}=0.2, h^{2}{ }_{20}=0.6\right)$ にとをまったこの傾问は $\mathrm{h}^{2}{ }_{10}$ が高い汪と顕著で, $\mathrm{h}^{2}{ }_{10}=0.6$ ては負の $\triangle \mathrm{CG} 2$ さえ 示した. $\mathrm{r}_{\mathrm{g} 0}$ が 0 の場合の $\triangle \mathrm{CG} 2$ は，初期には対照区と 大差はないが，後期には低下し， $\mathrm{r}_{\mathbf{g}}$ が正の場合と貝の 場合との中間を推移した。

日畜会報，55(5)：322-331，1984 